\title{
A new pyranoxanthone from the stems of Calophyllum membranaceum
}

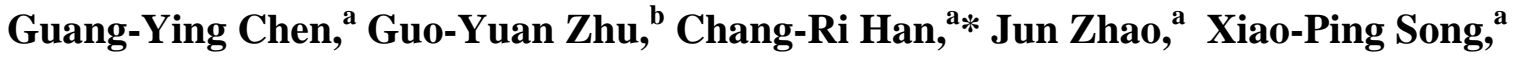 Wang-Fun Fong}

\author{
${ }^{a}$ Key Lab of Tropical Medicinal Plant Chemistry of Hainan Province, Department of Chemistry, \\ Hainan Normal University, Haikou 571158, P. R.China \\ ${ }^{b}$ Shenzhen Applied R\&D Centres of City University of Hong Kong, Shenzhen 518057, P. \\ R.China \\ E-mail: $\underline{\text { hchr@hainnu.edu.cn }}$
}

\begin{abstract}
A new pyranoxanthone, membraxanthone A (1) has been isolated from the ethanol extract of the stem of Calophyllum membranaceum, together with three known pyranoxanthones, nigrolineaxanthone W (2), calophinone (3) and caloxanthone I (4), and three known triterpenoids, friedelin (5), canophyllol (6) and canophyllic acid (7). Their structures were elucidated on the basis of chemical evidence and intensive spectroscopic analysis including HRESI-MS, 1D- and 2D-NMR. All of the compounds were isolated from this plant for the first time. These xanthones showed no activities towards human cancer cell lines KB, BC-1 and NCI-4460.
\end{abstract}

Keywords: Calophyllum membranaceum, Guttiferae, pyranoxanthones, membraxanthone A, triterpenoids

\section{Introduction}

Since the research group of the National Cancer Institute reported that $(+)$-calanolide A and inophyllum B isolated from Calophyllum lanigerum Miq. and C. inophyllum L., respectively, which showed strong activity against human immunodeficiency virus type 1 (HIV-1) ${ }^{1-2}$ a considerable number of studies have been performed on plants of the Calophyllum genus in the family of Guttiferae. Besides pyrancoumarins, ${ }^{3-5}$ the genus is considered as a rich source of xanthone derivatives which possess antibacterial, ${ }^{6}$ antifungal, ${ }^{7}$ antiviral, ${ }^{8}$ antimalarial, ${ }^{9}$ antiplatelet aggregation, ${ }^{10}$ immunomodulatory, ${ }^{11}$ and cancerchemopreventive activities. ${ }^{12}$

Calophyllum membranaceum Gaertn. et Champ. is an evergreen tree which is only distributed in the Hainan island, P. R. China. In a previous paper, we reported the isolation and identification of triterpenoids and flavonoids from the leaves of $C$. membranaceum. ${ }^{13}$ Further 
investigation on the stems of this plant led to the isolation of a new pyranoxanthone, membraxanthone A (1), together with three known pyranoxanthones, nigrolineaxanthone $\mathrm{W}(\mathbf{2})$, calophinone (3) and caloxanthone I (4), three known triterpenoids, friedelin (5), canophyllol (6) and canophyllic acid (7) (Figure 1). Their structures were established using spectral methods, especially 1D- and 2D-NMR. The xanthones were screened for their cytotoxicities against the human cancer cell lines KB, BC-1 and NCI-4460. Unfortunately, the results showed no activities towards these human cancer cells.
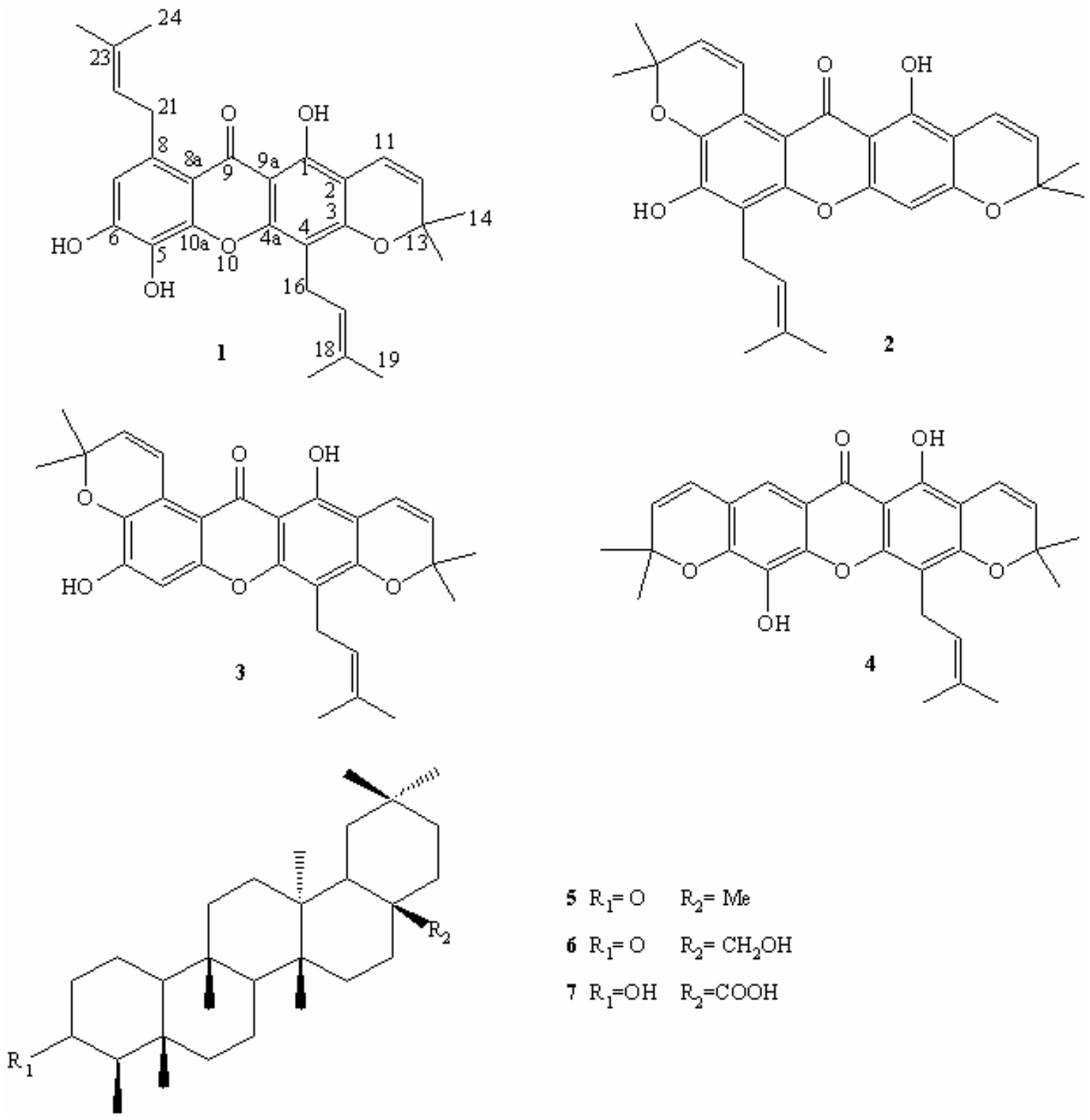

$$
\begin{array}{ll}
5 \mathrm{R}_{1}=\mathrm{O} & \mathrm{R}_{2}=\mathrm{Me} \\
6 \mathrm{R}_{1}=\mathrm{O} & \mathrm{R}_{2}=\mathrm{CH}_{2} \mathrm{OH} \\
7 \mathrm{R}_{1}=\mathrm{OH} & \mathrm{R}_{2}=\mathrm{COOH}
\end{array}
$$

Figure 1. Chemical Structures of the compounds 1-7. 


\section{Results and Discussion}

General Procedures. Column chromatography of the ethanol extract from the stem of the plant gave eight main fractions. Further purification of fraction 4 gave compound $\mathbf{1}$ as a yellow amorphous powder, which gave a positive $\mathrm{FeCl}_{3}$ test. Its molecular formula was determined as $\mathrm{C}_{28} \mathrm{H}_{30} \mathrm{O}_{6}$ on the basis of negative HR-ESI-MS m/z 461.1957 [M-H]'. The maximum UV absorption at $\lambda_{\max } 247,258,298$ and $319 \mathrm{~nm}$ suggested the existence of a xanthone skeleton. ${ }^{6}$ IR spectrum indicated the presence of hydroxyls $\left(3452 \mathrm{~cm}^{-1}\right)$ and a conjugated carbonyl group $\left(1654 \mathrm{~cm}^{-1}\right)$. The ${ }^{1} \mathrm{H}-\mathrm{NMR}$ (Table 1) showed an aromatic singlet proton at $\delta 6.77$ and a chelated hydroxyl proton at $\delta 13.5$. The ${ }^{13} \mathrm{C}-\mathrm{NMR}$ data (Table 1 ) demonstrated a carbonyl signal at $\delta$ 182.9 along with twelve aromatic carbon signals, six of them oxygenated at $\delta$ 157.2, 155.9, 153.6, 153.5, 150.7 and 139.6. The distribution of these aforementioned data was very similar to that of calophinone (3), except for the difference in ring A. The differences in ${ }^{1} \mathrm{H}-\mathrm{NMR}$ spectrum of compound $\mathbf{1}$ from those of $\mathbf{3}$ included the absence of two olefinic hydrogen resonances at $\delta$ $8.03(\mathrm{~d}, J=10 \mathrm{~Hz})$ and $5.83(\mathrm{~d}, J=10 \mathrm{~Hz})$, and one aromatic singlet proton at $\delta 6.85(\mathrm{~s})$, and the appearance of other one olefinic proton at $\delta 5.21(\mathrm{t}, J=6.8 \mathrm{~Hz})$, two methylene protons at 3.42 $(\mathrm{d}, J=6.0 \mathrm{~Hz})$ and one aromatic singlet proton at $\delta 6.77(\mathrm{~s})$. The differences in ${ }^{13} \mathrm{C}-\mathrm{NMR}$ spectrum of compound $\mathbf{1}$ from those of $\mathbf{3}$ are similar to those observed in ${ }^{1} \mathrm{H}-\mathrm{NMR}$ spectrum. These different signals between the two compounds suggested that the dimethylpyrene ring attached to C-8/C-7 in calophinone (3) had been opened to be a 3-methylbut-2-enyl substituent in compound 1. According to HMBC data, the methylene protons at $\delta 3.42(\mathrm{H}-21)$ correlated with carbons at $\delta 106.4(\mathrm{C}-7), \delta 111.3(\mathrm{C}-8 \mathrm{a})$ and $\delta 131.8(\mathrm{C}-23)$, while $\delta 5.21(\mathrm{H}-22)$ correlated with carbon at $\delta 127.2(\mathrm{C}-8)$, indicating that the isoprenyl group attached to $\mathrm{C}-8$. The aromatic singlet proton at $\delta 6.77$ caused cross peaks with carbons at $\delta 153.5$ (C-6), $\delta 139.6(\mathrm{C}-5), \delta 111.3(\mathrm{C}-8 \mathrm{a})$ and $\delta 21.3$ (C-21), which suggested the aromatic proton located on C-7. Therefore, membraxanthone A was assigned as 1, 5, 6-trihydroxy-4, 8-diisoprenyl-6', 6'-dimethyl pyrano(2', $3^{\prime}:$ 2, 3)xanthone.

In addition to compound 1, a number of other known compounds including three pyranoxanthones, nigrolineaxanthone $\mathrm{W}(2),{ }^{14}$ calophinone (3) ${ }^{15}$ and caloxanthone I (4), ${ }^{15}$ and three triterpenoids, friedelin (5), ${ }^{13}$ canophyllol (6) ${ }^{13}$ and canophyllic acid (7) ${ }^{13}$ were also isolated from the plant. They were identified by comparison with spectral data of related compounds. Physical and spectroscopic details obtained for the known compounds 2-7 are available in the Supplementary Information.

\section{Experimental Section}

General Procedures. The IR spectra were recorded on a Nicolet 5DX-FTIR spectrophotometer. The UV spectra were measured on a Shimadzu UV-240 spectrophotometer. The NMR spectra were recorded on a Bruker Avance-400 M instrument. ESI-MS were obtained on a Finnigan 
LCQ Advantage mass spectrometer and HRESI-MS on a API Qstar Pulsar-LC/TOF mass spectrometer. Silica gel (200-300 mesh, Qingdao marine Chemical, Qingdao, P.R.China), RP-18 silica gel (50 $\mu \mathrm{m}$, Merck, Darmstadt, Germany) and Pharmadex LH-20 (Amersham Pharmacia Biotech., Hongkong, P.R.China) were used for column chromatography. Precoated silica gel GF254 plates and RP-18 F254 plates (0.25 mm, Merck, Darmstadt, Germany) were used for TLC.

Table 1. NMR data of $\mathbf{1}$ (400 MHz for ${ }^{1} \mathrm{H}-\mathrm{NMR}$ and $100 \mathrm{MHz}$ for ${ }^{13} \mathrm{C}-\mathrm{NMR}, \mathrm{CDCl}_{3}$ )

\begin{tabular}{|c|c|c|c|c|}
\hline Carbons & DEPT & $\delta_{\mathrm{C}}(\mathrm{ppm})$ & $\delta_{\mathrm{H}}(\mathrm{ppm})$ & $\mathrm{HMBC}^{*}$ \\
\hline 1 & & 155.9 & & \\
\hline 2 & & 104.2 & & \\
\hline 3 & & 157.2 & & \\
\hline 4 & & 103.6 & & \\
\hline $4 a$ & & 153.6 & & \\
\hline 5 & & 139.6 & & \\
\hline 6 & & 153.5 & & \\
\hline 7 & $\mathrm{CH}$ & 106.4 & $6.77(1 \mathrm{H}, \mathrm{s})$ & $5,6,8 \mathrm{a}$ \\
\hline 8 & & 127.2 & & \\
\hline $8 \mathrm{a}$ & & 111.3 & & \\
\hline 9 & & 182.9 & & \\
\hline $9 \mathrm{a}$ & & 101.7 & & \\
\hline $10 \mathrm{a}$ & & 150.7 & & \\
\hline 11 & $\mathrm{CH}$ & 116.1 & $6.72(1 \mathrm{H}, \mathrm{d}, J 10 \mathrm{~Hz})$ & $1,3,13$ \\
\hline 12 & $\mathrm{CH}$ & 126.9 & $5.76(1 \mathrm{H}, \mathrm{d}, J 10 \mathrm{~Hz})$ & 2,13 \\
\hline 13 & & 77.7 & & \\
\hline 14 & $\mathrm{CH}_{3}$ & 28.2 & $1.47(3 \mathrm{H}, \mathrm{s})$ & 12,14 \\
\hline 15 & $\mathrm{CH}_{3}$ & 28.2 & $1.47(3 \mathrm{H}, \mathrm{s})$ & 12,14 \\
\hline 16 & $\mathrm{CH}_{2}$ & 26.0 & $4.34(1 \mathrm{H}, \mathrm{d}, J 7.2 \mathrm{~Hz})$ & $3,4 a, 18$ \\
\hline 17 & $\mathrm{CH}$ & 121.4 & $5.30(2 \mathrm{H}, \mathrm{t}, J 7.2 \mathrm{~Hz})$ & 4 \\
\hline 18 & & 135.8 & & \\
\hline 19 & $\mathrm{CH}_{3}$ & 18.1 & $1.88(3 \mathrm{H}, \mathrm{s})$ & 17,18 \\
\hline 20 & $\mathrm{CH}_{3}$ & 25.9 & $1.78(3 \mathrm{H}, \mathrm{s})$ & 17,18 \\
\hline 21 & $\mathrm{CH}_{2}$ & 21.3 & $3.42(1 \mathrm{H}, \mathrm{d}, J 6.8 \mathrm{~Hz})$ & $7,8 \mathrm{a}, 23$ \\
\hline 22 & $\mathrm{CH}$ & 122.4 & $5.21(2 \mathrm{H}, \mathrm{t}, J 6.8 \mathrm{~Hz})$ & 8 \\
\hline 23 & & 131.8 & & \\
\hline 24 & $\mathrm{CH}_{3}$ & 17.9 & $1.88(3 \mathrm{H}, \mathrm{s})$ & 22 \\
\hline 25 & $\mathrm{CH}_{3}$ & 25.8 & $1.67(3 \mathrm{H}, \mathrm{s})$ & 22 \\
\hline $1-\mathrm{OH}$ & & & $13.50(1 \mathrm{H}, \mathrm{s})$ & $2,9 \mathrm{a}$ \\
\hline
\end{tabular}

* long-range $1 \mathrm{H}-13 \mathrm{C}$ coupling, carbons to protons 
Plant materials. The stem of Calophyllum membranaceum Gaertn. et Champ. was collected in April 2004 from Lingshui County, Hainan Province, P. R. China, and authenticated by Professor Qiong-xin Zhong (Department of Biology, Hainan Normal University, Hainan Province). A voucher specimen (20040419) was deposited in the Herbarium of the Department of Chemistry, Hainan Normal University.

Extraction and isolation. The air-dried and powdered stem of C. membranaceum $(5 \mathrm{~kg})$ was extracted with $70 \%$ ethanol $(3 \times 30 \mathrm{~L}$, each for $7 \mathrm{~d})$ at room temperature. After evaporation of solvents in vacuo, $520 \mathrm{~g}$ residue was obtained. The extract was suspended in $\mathrm{H}_{2} \mathrm{O}(2.0 \mathrm{~L})$ and partitioned successively with petroleum ether $(3 \times 2 \mathrm{~L})$, chloroform $(3 \times 2 \mathrm{~L})$, ethyl acetate $(3 \times 2 \mathrm{~L})$ and $\mathrm{n}-\mathrm{BuOH}(3 \times 2 \mathrm{~L})$ to afford the corresponding fractions. The $\mathrm{CHCl}_{3}$ extract $(50 \mathrm{~g})$ was subjected to column chromatography (CC) on silica gel eluted with petroleum ether-acetone gradient (1000:1 $\rightarrow$ 0:100) to obtained eight fractions, namely A1-A8. Fraction A2(2.5g) was separated by silica gel CC eluted with petroleum ether-ethyl acetate(20:1-5:1) to obtain compound friedelin $(5,50 \mathrm{mg})$, canophyllol $(6,45 \mathrm{mg})$. Fraction A4 (2 g) was separated by silica gel CC eluted with petroleum ether-acetone $(20: 1,10: 1,5: 1,1: 1)$ to give four fractions, namely $\mathrm{B} 1-\mathrm{B} 4$. Fraction $\mathrm{B} 3$ was further purified by $\mathrm{C}-18$ reverse-phase silica gel $\mathrm{CC}$ eluted with $\mathrm{CH}_{3} \mathrm{OH}-\mathrm{H}_{2} \mathrm{O}(8: 2)$ to obtained compound membraxanthone $\mathrm{A}(\mathbf{1}, 20 \mathrm{mg})$, nigrolineaxanthone $\mathrm{W}$ $(2,15 \mathrm{mg})$ and calophinone $(3,35 \mathrm{mg})$. Fraction A6 (1.6 g) was subjected to silica gel CC eluted with petroleum ether-acetone $(10: 1 \rightarrow 1: 2)$ to give five fractions $\mathrm{C} 1-\mathrm{C} 5$. Fraction $\mathrm{C} 4$ was then purified by C-18 reverse-phase silica gel CC eluted with $\mathrm{CH}_{3} \mathrm{OH}-\mathrm{H}_{2} \mathrm{O}$ (4:6) and Sephadex LH$20\left(\mathrm{CH}_{3} \mathrm{OH}\right)$ to yield compound caloxanthone I $(4,15 \mathrm{mg})$, canophyllic acid $(7,30 \mathrm{mg})$.

Membraxanthone A 1. A pale-yellow needle. IR: 3455, 2960, 2926, 2858, 1662, 1600, 1458, 1293, 1127, $843 \mathrm{~cm}^{-1}$; UV (MeOH) $\lambda_{\max } \mathrm{nm}(\log \varepsilon): 216$ (1.73), 291 (1.91), 303 (1.96), 334 (1.66); ESI-MS (positive mode): $\mathrm{m} / \mathrm{z} 463.1[\mathrm{M}+\mathrm{H}]^{+}$; ESI-MS (negative mode): $\mathrm{m} / \mathrm{z} 461.3$ [M$\mathrm{H}]^{-}$; ESI-MS/MS (positive mode): $\mathrm{m} / \mathrm{z} 463.1[\mathrm{M}+\mathrm{H}]^{+}$to $407.1\left[\mathrm{M}+\mathrm{H}-\mathrm{C}_{4} \mathrm{H}_{8}\right]^{+}$; HR-ESI-MS (negative mode): $\mathrm{m} / \mathrm{z} 461.1957([\mathrm{M}-\mathrm{H}]]^{-}$, calculated for $\left.\mathrm{C}_{28} \mathrm{H}_{29} \mathrm{O}_{6}, 461.1964\right) ;{ }^{1} \mathrm{H}$ and ${ }^{13} \mathrm{C} \mathrm{NMR}$ see Table 1 .

Cytotoxicity bioassays. The cytotoxicity of compounds 1-6 was determined employing the colorimetric method as described by Skehan et al. ${ }^{16}$ The reference substance, ellipticine, exhibited cytotoxic activity against $\mathrm{KB}, \mathrm{BC}-1$ and NCI-4460 cells with $\mathrm{IC}_{50}$ values of $1.45,1.60$, and $0.56 \mathrm{mg} / \mathrm{mL}$, respectively.

Physical and spectroscopic details obtained for the known compounds 2-7 are available in the Supplementary Information. 


\section{Acknowledgements}

This work was supported by the National Natural Science Foundation of China (20562004), the key project of the Chinese Ministry of Education (No.207090) and the Natural Science Foundation of Hainan Province, China (20604).

\section{References and Notes}

1. Kashman, Y.; Gustafson, K. R.; Fuller, R. W.; Cardellina, J. H.; McMahon, J. B.; Currens, M. J. J. Med. Chem. 1992, 35, 2735.

2. Patil, A. D.; Freyer, A. J.; Eggleston, D. S.; Haltiwanger, R. C.; Bean, M. F.; Taylor, P. B. J. Med. Chem. 1993, 36, 4131

3. Dharmaratne, H. R. W.; Sajeevani, J. R. D. M.; Marasinghe, G. P. K. Phytochemistry 1998, 49, 995.

4. Itoigawa, M..; Ito, C.; Tan, H.T.W.; Kuchided, M.; Tokudad, H.; Nishinod, H. Cancer Lett. 2001, 169, 15.

5. McKee, T. C.; Fuller, R. W.; Covington, C. D.; Cardellina, I. J. H.; Gulakowski, R. J.; Krepps, B. L. J. Nat. Prod. 1996, 59, 754.

6. Khan, M. R.; Kihara, M.; Omoloso, A. D. Fitoterapia 2002, 73, 741.

7. Reyes-Chilpa, R.; Jimenez-Estrada, M.; Estrada-Muniz, E. J. Chem. Ecol. 1997, 23,1901.

8. Shen, Y. C.; Wang, L. T.; Khalil, A. T.; Chiang, L. C.; Cheng, P. W. Chem. Pharm. Bull. 2005,53, 244.

9. Hay, A. E.; He'lesbeux, J. J.; Duval, O.; LabaRed, M.; Grellier, P.; Richomme, P. Life Sciences 2004, 75, 3077.

10. Iinuma, M.; Tosa, H.; Tanaka, T.; Asai, F.; Kobayashi, Y.; Shimano, R. J. Pharm. Pharmacol. 1996, 48, 861.

11. Gonzalez, M. J.; Nascimento, M. S. J.; Cidade, H. M.; Pinto, M. M. M.; Kijjoa, A.; Anantachoke, C. Planta Med. 1999, 65, 368.

12. Yimdjo, M. C.; Azebaze, A. G.; Nkengfack, A. E.; Meyer, A. M.; Bodo, B.; Fomum, Z. T. Phytochemistry 2004, 65, 2789.

13. Chen, G. Y.; Han, C. R.; Song, X. P.; Huang, H. R.; Lin, Y. C. Chemistry and Industry of Forest Products 2003, 23, 73 (in Chinese with an English abstracts).

14. Deachathai, S.; Mahabusarakam W.; Phongpaichit S.; Taylor, W.C.; Zhang, Y.J.; Yang, C. R. Phenolic compounds from the flowers of Garcinia dulcis. Phytochemistry 2006, 67, 464.

15. Cheng, H. C.; Wang, L.T.; Khalil, A. T.; Chang, Y. T.; Lin, Y. C.; Shen, Y. C.; Pyranoxanthones from Calophyllum inophyllum. Journal of the Chinese Chemical Society 2004, 51, 431 .

16. Skehan, P.; Storeng, R.; Scudiero, D.; Monks, A.; McMahon, J.; Vistica, D.; Warren, J. T.; Bokesch, H.; Kenny, S.; Boyd, M. R. J. Natl. Cancer Inst. 1990, 82, 1107. 